\title{
LEADING PUBLIC TRANSPORTATION DRIVERS IN INTEGRATING TRAFFIC ETHICS BASED ON NATION CHARACTERS VALUE AT PADANG CITY
}

\author{
Erianjoni \\ Prodi Pendidikan Sosiologi, Fakultas Ilmu Sosial, Universitas Negeri Padang \\ erian_joni@yahoo.co.id \\ Jamalul Ihsan \\ Prodi Pendidikan Sosiologi, Fakultas Ilmu Sosial, Universitas Negeri Padang \\ jamalul.ihsan@yahoo.com
}

\begin{abstract}
This article discussed about the public transportation drivers traffic ethics. It was found that the drivers' attitude was accessed by societies from its good and bad or right and wrong side. These attitudes were the reflection of drivers' ethics. It was rarely seen that the public transportation drivers in Padang owned the ethics of Indonesian character such as religious, honest, care, responsible, discipline, and tolerant. As the result, there were some traffic phenomenon in Padang like traffic jam, accident, and violation. Therefore, it was crucial to improve the drivers' ethic which referred to Nation Character in order to create comfortableness in road traffic. The research result in this article tried to find the solution of the previous problem.
\end{abstract}

Keywords: ethics, traffic, character values

\section{Introduction}

The traffic problem nowadays has become a central issue in transportation field. Lots of critics and discussion about traffic management and public transportation were sent to government especially related institution. It seems that government is incapable to solve the problems. During holding the Ketupat operation 2014 or at the moment when the homecoming of IED MUBARAK $1415 \mathrm{H}$, the National Police Headquarters noted that 908 people die, 1505 people seriously injured, 5139 people minor injuries, and material losses amounted to 11.8 billion rupiahs caused by the traffic accident. This phenomenon happened at many regions in this country.

Geographically, West Sumatra has mountain topography and most of the roads are outflanked by hills and valleys on the right and left side of these roads. Within 10 months from January to September 2014, West Sumatra Traffic Police Directorate have noted 2424 traffic accident happened as follows 528 people die, 1233 people seriously injured, 2738 people minor injuries, with material losses amounted to 7.947.443.400 billion rupiahs . Then, the amount of violations was 
about 52.766 times. Among 19 police resorts in West Sumatra (Ditlantas Polda Sumbar 2014), the police resort of Padang reaches the highest number of motor cycle accident and other traffic violations. Until September 2014, 413 case of 2424 case of traffic accident in West Sumatra happened in Padang. Then, 1589 of 52776 case of violation in West Sumatra has also happened in Padang.

Beside prone to accidents and violations, Padang city is also easily to get traffic jam. Almost in all junctions in this city has been trapped in a traffic jam at particular hour. All the drivers do not want to calm themselves and be patient. All the drivers think that they have authorities but they forget that the pedestrian and the societies also have the same authorities. Driving vehicles in the street or road are every human's right but it's not an absolute right; it must be followed by a series of obligation and rules. The reason is because driving vehicles can a an activity that cause risks for ourselves or other ${ }^{1}$.

The first number of traffic violators is the driver of public transportation. From the time aspect, the public transportation drivers are placed at the first class of transportation in the city street. Almost 14 hours, they turn around the street every day. They leave home in the morning at 6 am and return home at $7 \mathrm{p}$ and psychologically, they obtain more pressure than other drivers. It can be seen from their efforts in paying the daily deposit, civilian deposit, retribution and others. They have to fulfill those payments every day. It seems these conditions will affect their discipline and ethics while driving at the highway.

The result of review on this phenomenon is expected to assist the writer in answering some signal element of traffic inconvenient which caused by traffic chaos, driving impoliteness, weak penalty by using a particular scientific and responsible review. Therefore, this research finding article have resulted a title of "LEADING PUBLIC TRANSPORTATION DRIVERS IN INTEGRATING TRAFFIC ETHICS BASED ON NATION CHARACTERS VALUE AT PADANG CITY"

\section{Literature Review: Developing Ethics and Discipline of Public Transportation Driver}

The style of driver and pedestrian in using the highway facilities were affected by their purpose and interest. A public transportation driver or "ojek" man which is pursued by reaching their daily payment will have a different attitude with woman who drives a luxurious car. In other side, a pedestrian will not feel save if the drivers do not give he or she a chance to across the road. From this explanation, it can be assumed that there is a difference of business and condition among the people even they have a same wants "Save on The Road". This might be reason why their attitude is different. This attitude is the reflection of their discipline ethics in using the railway facilities ${ }^{2}$.

An individual who is intensely running on the road is public transportation drivers. Other society only uses the highways as one of the tools for mobilization

\footnotetext{
${ }^{1}$ Trijon Aswin. 2007. Polemik Kerancuan Wewenang DLLAJ. Jakarta: Win Communication.

${ }^{2}$ Adiasasmita, Sakti Adji. 2011. Jaringan Transportasi. Yogyakarta: Graha Ilmu
} 
from one place to another. However, the public transportation drivers use the highways as the main medium to do their daily routines to run their main job. Referring to the pre-observation conducted, the process of developing drivers' ethics and discipline which conducted by the Traffic Directorate and Society Development in West Sumatra Police Directorate were formed in two types below.

\section{Socialization}

Socialization is conducted in two forms: direct socialization and the indirect one. The direct socialization is done by Sub-Directorate Division in Traffic Directorate and Society Development through directly meeting the public transportation driver on the road. The driver is given explanation about the negative and dangerous effect of not obeying the traffic rule. The implementation of this direct socialization is not conducted face to face only but also by using a vehicle with loudspeaker. The indirect socialization is undertaken by using radio, television, and newspaper. In addition, broadside and billboard are distributed in every strategic place.

\section{Giving Penalty}

The undisciplined drivers are subjected penalty by the field officer through giving them speeding ticket. The given penalty is proposed not only for upholding the rules but also to contribute the deterrent effect to the violating drivers. Thus, it can develop their ethics and disciplines. It is expected that by giving them penalty, the violators will remember that they have against the law. It is also hoped that they will not do the violations again ${ }^{3}$.

\section{Method}

This research was done in Padang. The approach of this research was qualitative, which tried to reveal and understand the reality in similar to what the informant seen. The qualitative approach is used to obtain depth data, the meaningful one ${ }^{4}$.

This research used a case study research in intrinsic style. It means the study was conducted by the researcher for obtaining a deep understanding ${ }^{5}$ in labeling the improper attitude on Minangkabaunese people. The techniques to gather the informant were through purposive sampling technique (conscious sampling technique). The total amount of the informants was 30 people consisted of character education experts, drivers, public transportation entrepreneur, passengers, transportation department party, and public transportation organization. The data collection in this research was 1) limited participation

${ }^{3}$ Budi, Gunawan dan Jen Z.A. Hans. 2006. Kiat Sukses Polisi Masa Depan. Jakarta: Personal Development Training.

${ }^{4}$ Sugiyono. 1995. Metode Penelitian Kualitatif. Jakarta: Universitas Indonesia; Sugiyono. 2015. Memahami Penelitian Kualitatif. Jakarta: Alfabeta.

${ }^{5}$ Sitorus, Felix. 1998. Penelitian Kualitatif Suatu Perkenalan. Bogor: IPB. 
observation technique and 2) interview; in-depth and structured interview, FGD then 3) documentation study.

On the next step, the data triangulation was conducted through comparing observation and interview data. The data were analyzed by using taxonomy analysis. The process was describing and revealing the taxonomies, classifications, and reference from the local terms. Then, the process continued to formulate the attitudes rules in a proper environment. This was proved right by societies through observing culture themes.

\section{Result and Discussion}

\section{The System of Developing Public Transportation Driver in Implementing Traffic Ethics Based on Nation Character}

There are some types of training to develop drivers' ethics. The efforts can be seen below.

a. Preventive Development: The establishment of pass-traffic rules for public transportation drivers

The drivers' establishment process (young age, low education, and others) is divided into three categories; Force, Can, Accustomed. (a) Force, it can be released through giving a clear action and making the deterrent effect to the violators. Usually, the penalty referred to the implemented law. As a result, drivers would rethink again to violate the rules. It was expected that it might give the deterrent effect to the drivers. In addition, it could minimize the aspect of negotiation and tolerance for the indiscipline drivers. (b) Can, the consequence of "can" was the driver would obey the ongoing rules and law process. In this context, the driver was ready and responsive to face all the rules.

\section{b. Repressive Leading}

\section{1) The reflection of violation evaluation in the field}

This step was done in order to measure how far the effectiveness of preventive development run well or explored the strong and weaknesses of that program. This reflection would ease which sections should be changed or maintained. Throughout reflection, it could measure person who had problems in executing those rules. It could be the police, dishubkominfo, drivers, or even passengers.

\section{2) Penalty Granting}

One of the establishing models in preventive stage is implementing penalty which could nurture and grow discipline of law enforcement officers, public transportation driver, and passengers. The penalty was given at the final stage when the educated establishment was not effectively working and to keep the authorization of law enforcement officers in the field. Penalty became crucial as it could be the power or accomplishment the ongoing development program. 


\section{3) The demolition of Driver and Passenger}

The effectiveness of police raid becomes the important point in building disciplines and nation character values. Periodically police raid is seen optimum to be implemented to the traffic violators. The raid is not only held toward the general condition of the vehicles but also the age of the driver. In addition, disciplining the trespasser passengers is also important.

\section{4) The Integral Leading System}

The integral leading system consisted as follow: (a) collaborative development; (b) continues coaching, (c) disciplined penalty, and (d) comprehensive leading development. The traffic ethics is the guidance of attitudes and rules which regulate relationship between humans in the traffic. Thus, it means ethics are not implemented in the daily life only. The daily life ethics concept is similar to the traffic ethics. It means we have to be tolerance, appreciate one another and not be selfish. The benefits of these traffic ethics are

1) able to manage individuals for not using the road offhanded.

2) able to create smoothness, regularity, safety and discipline.

3) able to decrease the amount of traffic accidents

Based on Law 22 of 2009, it is informed that traffic will be considered orderly, smooth, safe, and integrated if the ongoing traffic is held regularity in linked with the authorities and obligations of road users which is also seen free from obstruction and traffic jam. Without the existence of traffic ethics, the drivers will drive their car offhand without caring other person safeties. In addition, it may also cause traffic chaotic in the road. Thus, the accidents are regularly happened and the horrible traffic jam is possibly happened too.

The drivers' educations are also one way to overcome the traffic violators. Societies in another country have made driving school as an educational institution that aims to create a capable and skillful driver who can prevent the happening of traffic accidents. The schools were managed by professional that can overcome the traffics problem and also master in psychological knowledge and other social sciences. (http:// www.ekajayaberrindo.com)

Law 22 of 2009 about road transport traffic actually has entrusted the need of education and training for a person who wants to be public transportation driver. Those who offer application for obtaining driving license should have a certificate of competence from eligible education and training under the governmental legalization.

According to Handoyo, another thing which should be done is to recruit the driver who has the combination of technical skill in driving and traffic knowledge but also good personalities and attitude. It these have already been fulfilled, the welfare improvement for new bus management can contribute a positive impact. The driver will not get easily selfish and offhand in the street because of simple reason. Thus, the most important thing is the seeds then we can thing how to 
manage and cultivate these seeds. Therefore, the development of competency for the public transportation crews is very crucial to be risen. One of the way is through trainings process like Mental Improvement Action Program and the Discipline of Public Transportation Drivers (Heri, 2012: 45)

Generally, the modest drivers drive their own car limited only to integrate safety driving model that direct to the drivers' skill. In simply language, they were careful in driving their car. Defense driving is generally aimed to any model, ways, attitudes, and mental while driving. If the driver runs the model properly, it can give personal safety guarantee for them. In other case, more drivers have understood about this concept, it can decrease the amount of traffic accident victims. This aim is similar to what it is expected by the program of mental and discipline improvement of public transportation drivers. The building up models which is similar to the findings of this research are 1) preventively a) developing the traffic norms of public transportation driver; driver training (young age, lower education and others); 3 SA; Force-Can-Accustomed, (b) training for public transportation organization; the establishment process was done to open the effective communication between Dishubkominfo and Dirlantas Polri. This is used to create a media to create effective connection with the public transportation organization. The reason is because these organizations have more information about the attitudes of its members rather than the government itself. (c) Giving reward for the public transportation drivers. Reward is given to the good drivers who obey the norms. The type of the reward can be sticker or money, (d) the Pocket book Publishing. (2) Repressively; it can be conducted on this following ways (a) the reflection of violation evaluation outcome in the field. This can be done through measuring how far the effectiveness of preventive training to uncover the strong and weaknesses of the program, (b) penalty granting; one of the leading model in preventive stage is integrating educated and discipline penalty to the law enforcement officers, the public transportation drivers and the passengers (c) the disciplining process of driver and passengers, the effectiveness of raid becomes the important point in constructing the disciplines and nation characters. The raid can be done periodically without indiscriminately against traffic offenders. (3) Integral training system covers the following concerns (a) collaborative training, (b) continued establishments, (c) disciplinary penalty, and (d) comprehensive training material.

\section{Conclusion}

There are some systems of leading the public transportation drivers in integrating traffic ethics based on the nation character. The systems are as follow 1) preventively a) developing the traffic norms of public transportation driver (b) training for public transportation organization; (c) Giving reward for the public transportation drivers, (d) the Pocket book Publishing (2) Repressively; (a) the reflection of violation evaluation outcome in the field, (b) penalty granting; (c) the disciplining process of driver and passengers (d) integral training system. These two leading models are integrated to the nation character like discipline, honest, religious, and others. 


\section{REFERENCES}

Adiasasmita, Sakti Adji. 2011. Jaringan Transportasi. Yogyakarta: Graha Ilmu

Budi, Gunawan dan Jen Z.A. Hans. 2006. Kiat Sukses Polisi Masa Depan. Jakarta: Personal Development Training.

Sitorus, Felix. 1998. Penelitian Kualitatif Suatu Perkenalan. Bogor: IPB.

Sugiyono. 2015. Memahami Penelitian Kualitatif. Jakarta: Alfabeta. 1995. Metode Penelitian Kualitatif. Jakarta: Universitas Indonesia.

Trijon Aswin. 2007. Polemik Kerancuan Wewenang DLLAJ. Jakarta: Win Communication.

http://www.ekajayaberrindo.com/index.php/info-kegiatan/menyentuh-kesadaranpara-pengemudi-angkutan-umum-di-di-yogyakarta.html 